\title{
Effect of naloxone on circadian rhythms in lung function
}

\author{
S AL-DAMLUJI, PJ THOMPSON, KM CITRON, M TURNER-WARWICK \\ From the Brompton Hospital, London
}

ABSTRACT To determine whether the endogenous opioid peptides play a part in the pathogenesis $\stackrel{\infty}{\vec{N}}$ of asthmatic morning dipping, six patients with chronic asthma with a reproducible peak flow pattern of morning dipping were investigated in a double blind, randomised, crossover study of $\vec{A}$ naloxone versus placebo. Naloxone was given as a loading dose of $8 \mathrm{mg}$ followed by a continuous 을 infusion of $5.6 \mathrm{mg} / \mathrm{h}$ from midnight until $10 \mathrm{am}$ on two consecutive nights. Naxolone had no

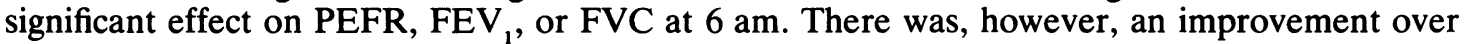
placebo values in all these indices between the hours of 8 am and $8 \mathrm{pm}$ on the day after the first naloxone infusion in all six patients. This effect was not observed after the second naloxone infusion.

There are many asthmatic patients whose "morning dipping" of lung function is refractory to treatment with bronchodilators and steroids. These patients constitute an important clinical problem in view of their susceptibility to severe and sometimes fatal airways obstruction during the sleeping hours. The aetiology of morning dipping, however, remains poorly understood.

There have been suggestions that the endogenous opioids may be concerned in the induction of airways obstruction in certain patients. The administration of chlorpropamide and alcohol to some diabetic patients may induce airways obstruction, ${ }^{1}$ which is attenuated by the prior administration of the specific opiate antagonist naloxone. ${ }^{2}$ Infusion of the enkephalin analogue desamino metenkephalin (DAMME; Sandoz) in one patient was followed by an asthmatic attack. ${ }^{2}$ Opioid peptides could mediate airways obstruction either by acting as neurotransmitters in autonomic ganglia ${ }^{3}$ or by producing a local hormonal effect; secretion of $\beta$-endorphin follows a circadian rhythm similar to that of cortisol, plasma concentrations being highest between 4 and $10 \mathrm{am} .{ }^{4}$ For these reasons we have studied the influence of an opiate antagonist (naloxone) on the asthmatic morning dip.

Address for reprint requests: Dr S al-Damluji, Metabolic Ward, St Bartholomew's Hospital, London EC1 A 7BE.

Accepted 6 September 1983

\section{Methods}

Six patients with chronic asthma were studied. They were chosen because their peak expiratory flow rate (PEFR) charts showed a regular pattern with the 6 am reading more than $25 \%$ lower than the highest daytime value. The patients' characteristics are outlined in table 1 . Informed, written consent was obtained from all the patients and the study was approved by the Brompton Hospital ethics committee.

Each patient was studied for 14 days, starting with a four day control period (fig 1). On the fourth night an intravenous infusion of either naloxone or 3 . placebo (naloxone vehicle provided by the manufacturers) was given from midnight until 10 am and the same infusion was repeated the following night. A 응 three day recovery period followed and the other infusion was given on the ninth and tenth nights in $\frac{7}{0}$ the same manner as above, followed by a second recovery period. The order in which the two active $\tilde{N}$ and two placebo infusions were given was random- $N$ ised and carried out under double blind conditions. N The infusion order was placebo followed by nalox- $\sigma$ one in three patients and naloxone followed by placebo in the other three. Naloxone $8 \mathrm{mg}$ was given as a loading dose over 20 minutes intravenously fol- $\$$ lowed by $56 \mathrm{mg}$ made up to $500 \mathrm{ml}$ with normal saline, infused at a constant rate of $5.6 \mathrm{mg}$ per hour.

PEFR was measured with a Wright's peak flow $\overrightarrow{\mathbb{D}}$ meter and forced expiratory volume in one second $\frac{?}{D}$ $\left(\mathrm{FEV}_{1}\right)$ and forced vital capacity (FVC) were meas-응 
Table 1 Details of the six patients with asthma (atopic in each case) and their respiratory function (values are means for the four control days, expressed as percentages of predicted values)

\begin{tabular}{|c|c|c|c|c|c|c|c|c|c|}
\hline \multirow{2}{*}{$\begin{array}{l}\text { Patient } \\
\text { No }\end{array}$} & \multirow{2}{*}{$\begin{array}{l}\text { Age } \\
(y)\end{array}$} & \multirow[t]{2}{*}{ Sex } & \multirow[t]{2}{*}{ Drugs } & \multicolumn{2}{|c|}{ PEFR (\% pred) } & \multicolumn{2}{|c|}{$F E V_{1}(\%$ pred $)$} & \multicolumn{2}{|c|}{ FVC (\% pred) } \\
\hline & & & & $6 \mathrm{am}$ & Peak & $6 \mathrm{am}$ & Peak & $6 \mathrm{am}$ & Peak \\
\hline 1 & 59 & $\mathbf{M}$ & $\begin{array}{l}\text { Prednisolone } 20 \mathrm{mg} \text { morning } \\
\text { Theophylline oral bd } \\
\text { Salbutamol nebulised qds, oral at night } \\
\text { Beclomethasone inhaler qds }\end{array}$ & 36 & 93 & 38 & 71 & 51 & 73 \\
\hline 2 & 26 & $F$ & $\begin{array}{l}\text { Prednisolone } 5 \text { mg morning } \\
\text { Theophylline oral bd } \\
\text { Salbutamol nebulised qds, oral bd } \\
\text { Beclomethasone inhaler qds }\end{array}$ & 40 & 100 & 35 & 86 & 37 & 77 \\
\hline 3 & 38 & $\mathbf{M}$ & $\begin{array}{l}\text { Prednisolone } 30 \text { mg morning } \\
\text { Theophylline oral bd } \\
\text { Salbutamol inhaler qds } \\
\text { Beclomethasone inhaler qds }\end{array}$ & 21 & 58 & 22 & 67 & 49 & 100 \\
\hline 4 & 39 & $F$ & $\begin{array}{l}\text { Prednisolone } 15 \mathrm{mg} \text { morning } \\
\text { Terbutaline oral at night } \\
\text { Theophylline oral tds } \\
\text { Beclomethasone inhaler qds }\end{array}$ & 27 & 100 & 33 & 89 & 32 & 84 \\
\hline 5 & 42 & $\mathbf{M}$ & $\begin{array}{l}\text { Prednisolone } 30 \text { mg morning } \\
\text { Theophylline oral bd } \\
\text { Terbutaline nebulised qds } \\
\text { Beclomethasone inhaler qds }\end{array}$ & 42 & 65 & 50 & 69 & 49 & 63 \\
\hline 6 & 18 & $\mathbf{F}$ & $\begin{array}{l}\text { Theophylline oral bd } \\
\text { Salbutamol nebulised qds } \\
\text { Beclomethasone inhaler qds }\end{array}$ & 48 & 96 & 42 & 67 & 45 & 64 \\
\hline
\end{tabular}

PEFR_peak expiratory flow rate; $\mathrm{FEV}_{1}$ —-forced expiratory volume in one second; FVC—forced vital capacity; bd—twice daily; qds—four times daily.

ured with a dry spirometer (Vitalograph). Recordings were made at two hourly intervals from 6 am until midnight on each day. The patients went to bed after the midnight recording and were woken at 6 am. They were all taking oral or inhaled bronchodilator drugs on waking and before retiring (table 1). No changes were made in the patients' medication throughout the study period and all drugs were given at the same time on each day.

Each morning the patients recorded the quality of the previous night's sleep on a visual analogue scale.

Statistical comparisons were carried out with the paired Student's $t$ test.

\section{Results}

There were no changes in the pattern of PEFR, $\mathrm{FEV}_{\text {, }}$, or FVC during the control period, indicating that the patients were in a steady state.

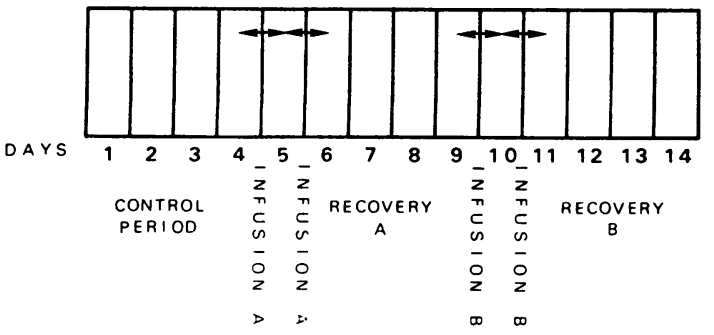

Fig 1 Diagrammatic representation of the study design.
Table 2 shows that there was no significant improvement over the placebo period in the $6 \mathrm{am}$ PEFR, FEV , or FVC measurements while the patients were having naloxone. Similarly, there was no significant difference between the 6 am measurements in the periods of recovery from naloxone and from placebo. The spirometric data obtained from patient 6 at times other than 6 am were incomplete so they were excluded from further analysis.

Figure 2 shows that there was a small improvement over the placebo period in all three indices of lung function between 8 am and $8 \mathrm{pm}$ after the first naloxone infusion. These results were significant for PEFR at $2 \mathrm{pm}(37 \%, \mathrm{p}<0.02$ by the paired $t$ test $)$ and for $\mathrm{FEV}_{1}$ at $2 \mathrm{pm}(13 \%, \mathrm{p}<0.02)$ and $4 \mathrm{pm}$ $(29 \%, \mathrm{p}<0.05)$. At these times the improvement was seen in all five patients. The mean maximum improvement in FVC was observed at $4 \mathrm{pm}(22 \%)$ but did not reach significance $(p>0 \cdot 1)$. The differences in lung function between the naloxone and placebo periods were observed only after the first infusion. The significant differences persisted, however, when the means of the first and second infusions were examined.

Patient 6 followed the same trend as the other five patients, with an improvement in all indices between $4 \mathrm{pm}$ and $10 \mathrm{pm}$ after naloxone compared with placebo.

The only adverse effect we encountered was in patient 2, who experienced an episode of shivering resembling a rigor. This started at 7.30 am during 
Table 2 Effects of naloxone and placebo infusions on respiratory function in five patients (means with SEM in parentheses)

\begin{tabular}{|c|c|c|c|c|c|c|}
\hline & & $\begin{array}{l}\text { Control } \\
\text { (mean of } 4 \text { days) }\end{array}$ & $\begin{array}{l}\text { Naloxone } \\
\text { (mean of } 2 \text { days) }\end{array}$ & $\begin{array}{l}\text { Recovery from } \\
\text { naloxone } \\
\text { (mean of } 3 \text { days) }\end{array}$ & $\begin{array}{l}\text { Placebo } \\
\text { (mean of } 2 \text { days) }\end{array}$ & $\begin{array}{l}\text { Recovery from } \\
\text { placebo } \\
\text { (mean of } 3 \text { days) }\end{array}$ \\
\hline PEFR ( $1 / \mathrm{min})$ & $\begin{array}{l}\text { Mean* } \\
6 \mathrm{am} \\
\text { Dip }{ }^{\dagger} \\
\text { \%dip }\end{array}$ & $\begin{array}{c}313 \\
(22) \\
173 \\
(21) \\
241 \\
(29) \\
58\end{array}$ & $\begin{array}{l}310 \\
(24) \\
188 \\
(37) \\
223 \\
(28) \\
54\end{array}$ & $\begin{array}{c}304 \\
(24) \\
174 \\
(20) \\
232 \\
(38) \\
57\end{array}$ & $\begin{array}{c}295 \\
(50) \\
190 \\
(30) \\
220 \\
(35) \\
54\end{array}$ & $\begin{array}{l}308 \\
(26) \\
188 \\
(19) \\
223 \\
(31) \\
54\end{array}$ \\
\hline $\mathrm{FEV}_{1}(\mathrm{ml})$ & $\begin{array}{l}\text { Mean* } \\
6 \text { am } \\
\text { Dip } \dagger \\
\text { \%dip }\end{array}$ & $\begin{array}{c}1822 \\
(129) \\
1161 \\
(151) \\
1186 \\
(179) \\
51\end{array}$ & $\begin{array}{c}1818 \\
(158) \\
1112 \\
(250) \\
1230 \\
(176) \\
53\end{array}$ & $\begin{array}{c}1785 \\
(157) \\
1211 \\
(103) \\
1031 \\
(168) \\
46\end{array}$ & $\begin{array}{c}1668 \\
(179) \\
1154 \\
(229) \\
1092 \\
(227) \\
49\end{array}$ & $\begin{array}{c}1836 \\
(160) \\
1301 \\
(112) \\
1060 \\
(108) \\
45\end{array}$ \\
\hline FVC (ml) & $\begin{array}{l}\text { Mean* } \\
6 \text { am } \\
\text { Dip }{ }^{\dagger} \\
\text { \%dip }\end{array}$ & $\begin{array}{c}2575 \\
(176) \\
1800 \\
(336) \\
1387 \\
(294) \\
44\end{array}$ & $\begin{array}{c}2612 \\
(242) \\
1812 \\
(279) \\
1333 \\
(264) \\
42\end{array}$ & $\begin{array}{c}2514 \\
(273) \\
1844 \\
(171) \\
1189 \\
(204) \\
39\end{array}$ & $\begin{array}{c}2447 \\
(211) \\
2041 \\
(257) \\
1017 \\
(352) \\
33\end{array}$ & $\begin{array}{c}2616 \\
(257) \\
2005 \\
(194) \\
1183 \\
(95) \\
37\end{array}$ \\
\hline
\end{tabular}

*Mean of all recordings from 6 am to midnight.

$\dagger$ Dip $=$ peak -6 am value .

PEFR - peak expiratory flow rate; FEV 1 -forced expiratory volume in one second; FVC-forced vital capacity.
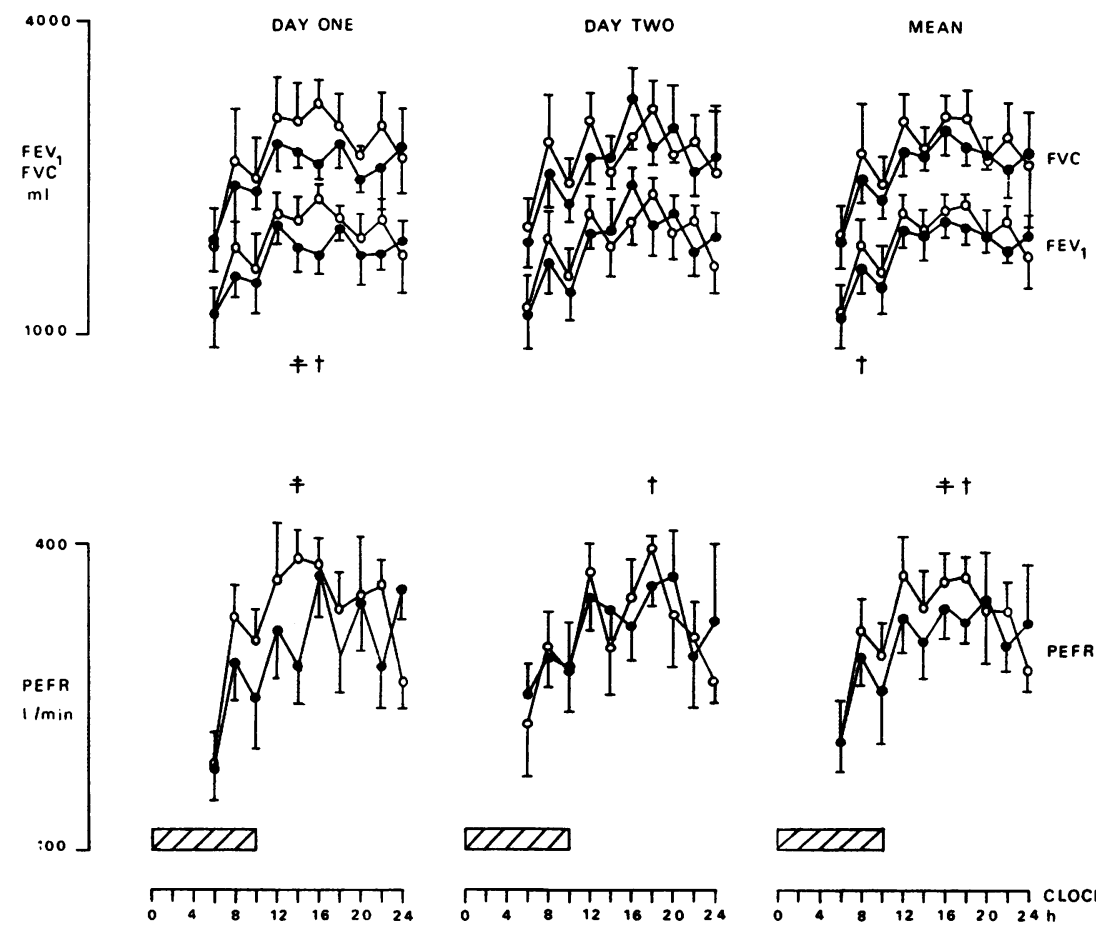

Fig 2 Peak expiratory flow rate (PEFR), forced expiratory volume in one second (FEV), and forced vital capacity (FVC) (means and SEM) after in fusion of naloxone or placebo (shaded area) from midnight until 10 am in five patients. Open circles represent naloxone and closed circles placebo. $\dagger p<0.05 * p<0.02$ (paired t test). The statistical symbols in the upper part of the figure refer to FEV, and in the lower part to PEFR. 
the second naloxone infusion and ceased 15 minutes after the infusion was terminated, only to recur for five minutes several hours later. During these episodes the patient was afebrile and had no other abnormal signs. She had not experienced any adverse effect during the first naloxone infusion. Shivering after administration of naloxone has previously been described. ${ }^{5}$ There were no other effects which could have enabled the patients to distinguish between naloxone and placebo.

All patients slept well during the nights when they had the infusions and there was no difference in their assessment of sleep quality between the naloxone and the placebo nights, which is in agreement with previous observations. ${ }^{6}$

\section{Discussion}

Although circadian rhythms of PEFR are observed in normal individuals, ${ }^{7}$ the mechanism whereby this phenomenon is exaggerated in asthmatic patients is unclear. Sleep studies have shown no significant differences in the electroencephalographic stages between asthmatic and normal subjects, and there is no association of attacks of nocturnal asthma with any particular sleep stage. ${ }^{8}$ Furthermore, most subjects still show dips in the morning if their sleep is disrupted, ${ }^{9}$ suggesting that morning dipping is not caused by sleep per se. Hypothalamo-pituitaryadrenal function is normal in asthmatic patients ${ }^{1011}$ and infusions of hydrocortisone to abolish the circadian rhythm of plasma cortisol do not abolish the circadian pattern of PEFR. ${ }^{12}$ Although there is a temporal relationship between the nadirs of PEFR and urinary ${ }^{13}$ and plasma ${ }^{14}$ catecholamine concentrations, nocturnal administration of salbutamol does not abolish the morning dip in PEFR. ${ }^{15}$ The PEFR response to adrenaline is similar at 4 am and $4 \mathrm{pm}$, suggesting that adrenoceptor dysfunction is not relevant. ${ }^{16}$ There is apparently no relationship between morning dipping and house dust allergy, ${ }^{17}$ nor does the exaggerated dip seem attributable to the recumbent posture. ${ }^{18}$ Differences in drug pharmacokinetics between day and night have been suggested, ${ }^{19}$ but this idea needs further investigation.

The apparent lack of progress in understanding the aetiology of the asthmatic morning dip and the suggestion that the endogenous opioids might play a part in airways obstruction prompted us to investigate the role of these peptides in the mediation of the morning dip, using an opiate antagonist.

This study provides no support for the hypothesis that the opioid peptides are mediators of morning dipping as there was no improvement in lung function at 6 am on the mornings of naloxone infusion over placebo mornings. Although opioid receptors have been described with a low affinity for naloxone,$^{20}$ this is unlikely to explain our inability to show an effect on the morning dip as the dose of naloxone used (a total of $64 \mathrm{mg}$ per patient) was many times larger than the dose used clinically to block the effects of exogenous opiates $(0.4-0.8 \mathrm{mg})$. Weinberger and colleagues ${ }^{21}$ recently found that naloxone does not inhibit the asthmatic reaction caused by cold air inhalation. They concluded that the endogenous opioid peptides were not concerned in the mediation of airways obstruction in their experimental model, which is in accordance with our results.

The small improvement in lung function between $8 \mathrm{am}$ and $8 \mathrm{pm}$ on the first day after naloxone infusion was unexpected. The improvements were significant for PEFR and FEV, but not FVC, presumably because of the small number of patients studied. As the infusions started at midnight and terminated at $10 \mathrm{am}$, the absence of an effect at 6 am suggests a delayed effect of naloxone on lung function. The mechanism is unclear: naloxone has been shown to increase circulating adrenocorticotrophic hormone (ACTH) and cortisol in normal man $^{22}$ but four of our patients were taking large doses of prednisolone, which was presumably suppressing their hypothalamo-pituitary-adrenal axes; so an effect of naloxone on ACTH secretion in these circumstances seems unlikely.

No explanation can be offered for the lack of improvement in lung function after the second naloxone infusion, but it is tempting to speculate that naloxone increases $\beta$-endorphin secretion by interrupting a negative feedback loop and the resulting delayed high opioid levels may account for the diminished naloxone effect on the second infusion day.

The timing of the infusions was designed to cause the least interruption to the patients' sleep and to answer the question: does naloxone infused overnight abolish asthmatic morning dipping? We believe this study has provided a clear answer to this question in that there was no improvement in lung function at 6 am during naloxone infusion compared with placebo. The small delayed effect of naloxone on lung function is unexplained and requires confirmation and further study.

We thank Professor GM Besser and Dr A Grossman for discussing the study, Endolaboratories for supplying naloxone and placebo, $\mathrm{MH}$ Stokoe and $\mathrm{T}$ Root for pharmaceutical help, Miss Dawn Beaumont for computing, and our consultant colleagues for allowing us to study their patients. 


\section{References}

${ }^{1}$ Leslie RDG, Pyke DA. Chlorpropamide-alcohol flushing: a dominantly inherited trait associated with diabetes. $\mathrm{Br}$ Med J 1978;ii:1519-21.

${ }^{2}$ Leslie RDG, Bellamy D, Pyke DA. Asthma induced by enkephalin. Br Med J 1980;i:16-8.

${ }^{3}$ Schultzberg M, Hokfelt T, Lundberg JM, Terenius L, Elfvin LG, Elde R. Enkephalin-like immunoreactivity in nerve terminals in sympathetic ganglia and adrenal medulla and in adrenal medullary gland cells. Acta Physiol Scand 1978;103:475-7.

${ }^{4}$ Dent RMM, Guilleminault C, Albert LH, Posner BI, Cox BM, Goldstein A. Diurnal rhythm of plasma immunoreactive $\beta$-endorphin and its relationship to sleep stages and plasma rhythms of cortisol and prolactin. J Clin Endocrinol Metabol 1981:52:942-7.

5 Tammisto T, Tigerstedt I. Restlessness and shivering after naloxone reversal of fentanyl supplemented anaesthesia. Acta Anaesth Scand 1979;23:51-6.

${ }^{6}$ Davis GC, Duncan WC, Gillin JC, Bunney WR. Failure of naloxone to affect human sleep. Commun Psychopharmacol 1977;1:489-92.

${ }^{7}$ Hetzel MR, Clark TJH. Comparison of normal and asthmatic circadian rhythms in peak expiratory flow rates. Thorax 1980;35:732-8.

${ }^{8}$ Kales A, Beall GN, Bajor GF, Jacobson A, Kales JD. Sleep studies in asthmatic adults: relationship of attacks to sleep stage and time of night. J Allergy 1968;41:164-73.

${ }^{9}$ Hetzel MR, Clark TJH. Does sleep cause nocturnal asthma? Thorax 1979;34:749-54.

${ }^{10}$ Collins JV, Bellamy D, Britton MG, Townsend J, Brown DJ. Hypothalamo-pituitary-adrenal function in intrinsic non-atopic asthma. Thorax 1975;30:578-81.

" Morrish DW, Sproule BJ, Aaron TH, Outhet D, Crockford PM. Hypothalamic-pituitary-adrenal function in asthma. Chest 1979;75:161-6.
12 Soutar CA, Costello J, Ijaduola O, Turner-Warwick M. Nocturnal and morning asthma. Relationship to plasma corticosteroids and response to cortisol infusion. Thorax 1975;30:436-40.

${ }^{13}$ Soutar CA, Carruthers M, Pickering CAC. Nocturnal asthma and urinary adrenaline and noradrenaline secretion. Thorax 1977;32:677-83.

${ }^{14}$ Barnes P, Fitzgerald G, Brown M, Dollery C. Nocturnal asthma and changes in circulating epinephrine, histamine and cortisol. N Engl J Med 1980;303:263-7.

${ }^{15}$ Fairfax AJ, McNabb WR, Davies HJ, Spiro SG. Slowrelease oral salbutamol and aminophylline in nocturnal asthma: relation of overnight change in lung function and plasma drug levels. Thorax 1980;35:526-30.

${ }^{16}$ Barnes PJ, Fitzgerald GA, Dollery CT. Circadian variation in adrenergic responses in asthmatic subjects. Clin Sci 1982;62:349-54.

${ }^{17}$ Connolly CK. House dust mite hypersensitivity: morning dipping and severity of wheeze. Respiration 1981; 42:258-62.

${ }^{18}$ Clark TJH, Hetzel MR. Diurnal variation of asthma. $\mathrm{Br}$ $J$ Dis Chest 1977;71:87-92.

${ }^{19}$ McAllister WAC, Mitchell DM, Collins JV. Prednisolone pharmacokinetics compared between night and day in asthmatic and normal subjects. $\mathrm{Br} J$ Clin Pharmacol 1981;11:303-4.

${ }^{20}$ Lord JAH, Waterfield AA, Hughes J, Kosterlitz HW Endogenous opioid peptides: multiple agonists and receptors. Nature 1977;267:495-9.

${ }^{21}$ Weinberger SE, Weiss S, Johnson TS, Von Gal E, Balsavich L. Naloxone does not affect broncho. constriction induced by isocapnic hyperpnoea of subfreezing air. Am Rev Respir Dis 1982;126:468-71.

${ }^{22}$ Volavka J, Cho D, Mallya A, Bauman J. Naloxone increases ACTH and cortisol levels in man. $N$ Engl J Med 1979;300:1056-7. 
observations between ourselves and Dr Kay and his colleagues may be explicable by differences in the route of administration of monocrotaline and the size of the animals used. (ii) We find lung hyperplasia, right ventricular hypertrophy, and reductions in serotonin transport in the absence of changes in lung total ACE. (iii) If hyperplasia of an organ occurs, the expression of enzyme activities on a total organ basis is appropriate. (iv) We have observed right ventricular hypertrophy only after the development of lung hyperplasia. It is implied by Drs Keane and Kay that right ventricular hypertrophy may be obtained after monocrotaline administration in the absence of lung hyperplasia. This is an important statement, and should be appropriately documented (no data on organ weights are presented in their report), as it has a bearing on hypotheses concerning the inducement of hypertrophy.

RYAN J HUXTABLE W MARK LAFRANCONI Department of Pharmacology University of Arizona Health Sciences Center Tucson, Arizona 85724

USA

' Huxtable R, Ciaramitaro D, Eisenstein D. The effect of a pyrrolizidine alkaloid, monocrotaline, and a pyrrole, dehydroretronecine, on the biochemical functions of the pulmonary endothelium. Mol Pharmacol 1978;14:1189-203.

${ }^{2}$ Kay JM, Heath D. Crotalaria spectabilis: the pulmonary hypertension plant. Springfield: Charles C Thomas, 1969.
Purulent pericarditis with tamponade: a rare complication of pectus repair

SIR,-Since the introduction of antibiotics purulent pericarditis has become uncommon and most cases occur after cardiac surgery. However, we have recently encountered such a case following surgery for pectus excavatum.

A 22 year old woman developed bilateral pleural effusions one month after classical repair of severe asymmetrical pectus excavatum. She also presented with clinical features of a right calf vein thrombosis. She was anticoagulated with heparin, but sustained a cardiorespiratory arrest 45 days after operation and was thought to have sustained a massive pulmonary embolism. When the chest was opened, however, the pericardium was found to contain a tense collection of pus. This was drained, with immediate improvement in the circulation. Her subsequent postoperative course was uneventful.

Occasional reports of purulent pericarditis following oesophageal perforation have appeared ${ }^{1}$ and on one occasion this presented as pericardial tamponade. ${ }^{2}$ Purulent pericarditis rarely occurs after surgery when the pericardium is not opened ${ }^{3}$ and to our knowledge this is the first report of pyogenic tamponade complicating repair of pectus excavatum.

IJ REECE

B SETHIA

KG DAVIDSON

Department of Cardiac Surgery Royal Infirmary Glasgow G31 2ER

${ }^{1}$ Bozer AY, Saylam A, Ersoy U. Purulent pericarditis due to perforation of oesophagus with foreign body. $J$ Thorac Cardiovasc Surg 1974;67:590-2.

${ }^{2}$ Welch TG, White TR, Lewis RP, Altieri PI, Vasko JS, Kilman JW. Oesophagopericardial fistula presenting as cardiac tamponade. Chest 1972;62:728-31.

${ }^{3}$ Bulkley BN, Klacsmann PG, Hutchins GM. A clinicopathological study of post-thoracotomy purulent pericarditis. A continuing problem of diagnosis and therapy. $J$ Thorax Cardiovasc Surg 1977;73:408-12.

\section{Notices}

\section{British Thoracic Society}

7-9 May 1984

Joint Meeting with Australian Thoracic Society in Adelaide (meeting with chest physicians in Sydney 4 or 5 May)

4-6 July 1984

Brighton: Metropole Hotel (NB abstracts required by 19 April)

6-7 December 1984

London: Kensington Town Hall

3-5 July 1985

York University

\section{Correction}

Effect of naloxone on circadian rhythm in lung function

We regret that in the paper by Dr S Al-Damluji and others (December 1983, pp914-8) there is an error in the caption to table 2: "in five patients" should be "in six patients." 